\title{
Is blind faulting truly invisible? Tectonic-controlled drainage evolution in the epicentral area of the May 2012, Emilia-Romagna earthquake sequence (northern Italy)
}

\author{
Pierfrancesco Burrato ${ }^{\star}$ Paola Vannoli, Umberto Fracassi, Roberto Basili, Gianluca Valensise
}

Istituto Nazionale di Geofisica e Vulcanologia, Sezione Roma 1, Roma, Italy

\author{
Article history \\ Received August 3, 2012; accepted August 21, 2012. \\ Subject classification: \\ Blind faulting, Tectonic geomorphology, Seismogenic source, 2012 Emilia-Romagna earthquake sequence, Po Plain.
}

\section{Introduction}

For decades, alluvial plains have been the areas of the fastest population growth over most of the globe. Modern societies demand growing extensions of flat and easily accessible land to accommodate the swelling urban areas, booming industrial districts, large power plants, and multi-runway airports. But how can we tell if such flat areas hide large active faults? How can we assign a significant pre-instrumental earthquake to its causative source? In other words, how can modern societies deal with buried, that is to say, 'invisible' faults, and with the elusiveness of the hazards they can pose?

The issue of blind faulting became widely debated in the Earth sciences community in 1989, following the publication of a summary on a sequence of 'hidden earthquakes' that hit central and southern California, USA, between 1983 and 1987, and following the October 17, 1989, Loma Prieta, California, earthquake $\left(M_{W}\right.$ 6.9). These earthquakes shattered the accepted belief that large earthquakes are associated with large topographic contrasts; i.e., that they usually take place in mountainous terrains, and that their causative faults are expressed at the surface. Stein and Yeats [1989] spelled out clearly that "...large earthquakes can take place not only on faults that cut the Earth's surface, but also on 'blind' faults under folded terrain". Due to the growing concentrations of population and infrastructures in low topography areas, although such earthquakes might pose comparable hazards, they can come with substantially greater risk than earthquakes that occur in hilly or mountainous terrains.

How can we make the invisible faults 'visible'? Where are these faults hidden? Can we locate them through studies of the local geomorphology? We take on these challenges and show how continuing slip on the faults responsible for the May 2012 Emilia-Romagna, northern Italy, earthquake sequence (two mainshocks of $M_{L} 5.9$ and 5.8, on May 20 and 29,2012 , respectively) also controlled the drainage evolution of the southern Po Plain during the Holocene. Recent earth- quakes worldwide show that the hazard posed by blind and hard-to-identify faults is a critical issue even in countries where active fault studies are advanced. Such is the case of the March 25, 2007, Noto-Hanto, Japan, earthquake $\left(M_{W} 6.9\right)$, and the September 4, $2010\left(\mathrm{M}_{\mathrm{W}}\right.$ 7.1) and February 22, 2011 $\left(\mathrm{M}_{\mathrm{W}}\right.$ 6.3) earthquakes near Christchurch, New Zealand, all of which were largely unexpected.

Not surprisingly, the identification of active faults in flat areas is fraught with conceptual and practical difficulties, some of which arise from the diffuse perception that 'flat' equals 'stable', and that 'invisible' equals 'absent'. Whether or not a large active fault can be seen at the surface depends primarily on a combination of geodynamic circumstances, the local structural setting, the geometry of the faulting (the depth and dip), and the competition of tectonic versus sedimentation rates. In this respect, the Po Plain is especially challenging due to the combination of: a) low strain rates; b) infrequent and moderate-sized earthquakes; c) regionalscale tectonic strains that are larger than those caused by localized faulting; d) sedimentary rates much higher than tectonic rates; and e) locally, large man-induced elevation changes overshadowing those caused by genuine tectonic activity. More specifically, the blind nature of faulting in the Po Plain is a result of two fundamental geodynamic occurrences: (i) the Plio-Quaternary sedimentation rates (i.e., contemporary to the tectonic phases responsible for thrust development) induced by regional-scale uplift of the adjacent Apennine and Alpine belts are faster than the rates at which individual buried anticlines generate topographic relief [e.g., Bartolini et al. 1996]; and (ii) progressive burial of active structures was favored by the creation of accommodation space due to the subsidence of the northern Apennines foredeep, as shown by the dip in the foreland monocline beneath the northern Apennines [Mariotti and Doglioni 2000]. As a result, the majority of the presently active structures are buried beneath a largely irregular sedi- 


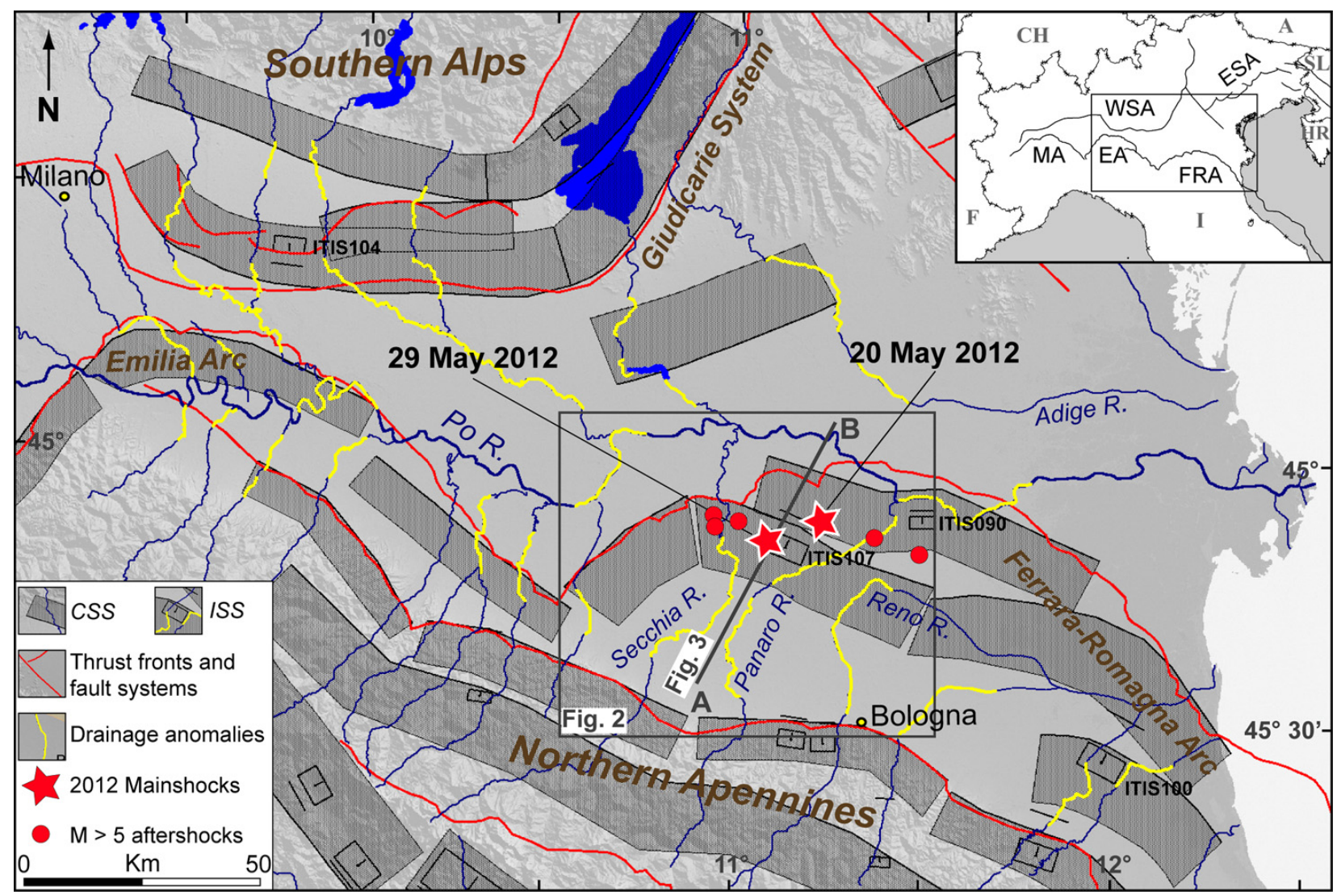

Figure 1. Seismotectonic sketch of the Po Plain and its fluvial system. Drainage anomalies are highlighted in yellow [from Burrato et al. 2003]. Red lines are the main thrust fronts or fault systems of the northern Apennines and southern Alps. Individual Seismogenic Sources (ISS) and Composite Seismogenic Sources (CSS) are from DISS 3.1.1. ITIS090, Ferrara Individual Source (http:/ / diss.rm.ingv.it/dissHTML/ITIS090INF.html); ITIS107, Mirandola Individual Source (http:/ / diss.rm.ingv.it/dissHTML/ITIS107INF.html); MA, Monferrato Arc, EA, Emilia Arc; FRA, Ferrara-Romagna Arc; WSA, western southern Alps; ESA, eastern southern Alps. Boxed area, detail shown in Figure 2.

mentary apron that is up to several thousand meters thick.

Under these conditions, the identification and characterization of seismogenic sources calls for an approach that integrates high-resolution subsurface geological and geophysical data with unconventional morphotectonic analysis that detects changes in the local elevation or topographic gradient. Drainage patterns have been demonstrated to be the most sensitive landscape feature to subtle topographic gradient changes [e.g., Schumm and Khan 1972, Holbrook and Schumm 1999], and they are therefore a key element in our approach. The combination of the lack of inherited landscape, as most of the plain was formed during the Last Glacial Maximum or is from the Holocene age, with the absence of significant lithological discontinuities makes the use of geomorphic analyses of the drainage evolution suitable for unveiling subtle ongoing tectonic deformation.

Based on these principles, Burrato et al. [2003] mapped numerous drainage anomalies associated with buried active structures in the Po Plain. The main result of their investigation, which was later augmented by detailed studies of the subsurface stratigraphic and sedimentary configuration [Toscani et al. 2009], was the foundation for a seismogenic source model on the Po Plain (Figure 1). These data have been incorporated into the Database of Seismogenic Sources (http:/ / diss.rm.ingv.it/diss/) [Basili et al. 2008, DISS Work- ing Group 2010]. The May 20 and 29, 2012, Emilia-Romagna earthquakes $\left(\mathrm{M}_{\mathrm{L}} 5.9\right.$ and 5.8, respectively) were most likely generated by two of the seismogenic sources that were identified through this approach. Hence they support the reliability of this approach and its applicability to a wider scale and in similar tectonic contexts anywhere. Quaternary folding is driven by active blind faulting (e.g., Andean adjacent foreland region) [Costa et al. 2006]. The Emilia-Romagna earthquakes also provided clear evidence that a fault-based model is of critical relevance in seismic hazard studies, especially in areas where earthquakes are dispersed and infrequent, such as the Po Plain.

\section{Geological and seismological framework}

The Po Plain comprises the foreland of the S-verging central-southern Alps and of the N-NE-verging northern Apennine fold-and-thrust belts, which developed in response to the continuous convergence of the African and European plates, from the Cretaceous onwards [Carminati and Doglioni 2012, and references therein]. Its physiographic boundaries correspond to the contact between the Quaternary alluvium of the plain and the pre-Quaternary rocks exposed along the mountain fronts.

The Plio-Quaternary sedimentary sequence that has filled in the Po Plain is characterized by an uneven thickness, 
which ranges from several thousand meters thick to a few tens of meters thick atop the crests of the buried anticlines [Bigi et al. 1992]. The relatively short wavelength variations $(3-10 \mathrm{~km})$ of the geometry of the sedimentary sequence due to the local tectonic activity are superimposed on much longer wavelength signals due to the larger subsidence of the northern Apennines foredeep, with respect to that of the southern Alps [Mariotti and Doglioni 2000]. The main consequence of these relationships is that the thickness of the clastic wedge generally increases southwards; i.e., towards the northern Apennines mountain front. Similarly, the depth of the basal detachments of the thrust wedge increases going towards the southern margin of the Po Plain, where the outermost thrust fronts of the northern Apennines belt are buried below Plio-Quaternary marine and continental deposits. These fronts are recognized as three complex fold systems: the Monferrato, Emilia, and Ferrara-Romagna Arcs, from west to east (Figure 1). Starting in the 1940's, these buried structures were extensively explored by seismic reflection lines and deepwell logs that were performed for oil exploration.

Ongoing deformation in the Po Plain as recorded by global positioning system data shows limited shortening, with rates of a few mm/y [e.g., Devoti et al. 2011]. Borehole breakout data show Sh-max axes perpendicular to the trend of the buried thrust fronts [Montone et al. 2012], and ca. N-S directed Sh-max along the thrusts of the Ferrara-Romagna Arc [Montone and Mariucci, 1999]. Evidence for earthquake activity of the frontal thrusts of the northern Apennines and southern Alps is supplied by macroseismic and instrumental data [Castello et al. 2006, Guidoboni et al. 2007, ISIDe Working Group 2010, Rovida et al. 2011], with the latter indicating dominant reverse faulting [e.g., Pondrelli et al. 2006]. Accordingly, the 2012 sequence (which consisted of more than 2,400 aftershocks) showed pure reverse faulting generated by the blind thrusts of the western Ferrara Arc, which activated a 50$\mathrm{km}$-long stretch of this buried thrust, and the Sh-max axes obtained from the focal mechanisms are perpendicular to the buried fronts. Most of the sequence occurred between $1 \mathrm{~km}$ and $12 \mathrm{~km}$ in depth, above the basal detachment of the outer thrust fronts of the northern Apennines [see Scognamiglio et al. 2012, this volume].

\section{Methods}

Through extensive analysis of the river network of the whole Po Plain, Burrato et al. [2003] identified several significant drainage anomalies. The wavelength of these anomalies was seen to be comparable to that of tectonic structures of crustal significance, and suggested the presence of buried growing folds beneath the river diversions. This analysis led to the compilation of a geographic information system database of anomalous river reaches to be compared with structural and earthquake data.

The method adopted to identify an anomalous reach in- cludes an analysis of the local topographic gradients and of the mean flow directions of the drainage network. It assumes that if the two vectors diverge beyond a given threshold, the river diversion must have been driven by a force that was independent of the natural evolution of the stream channel (Figure 2). Burrato et al. [2003] conventionally defined a drainage anomaly as a difference in the two vectors of $>10^{\circ}$. However, the length of the 'anomalous reach' (adjusted to the river size) must also be considered; i.e., the distance over which the divergence persists. This is important, to avoid mistaking natural irregularities for anomalous reaches, such as large meanders. Hence, an anomalous reach is further clarified and includes divergence between the two vectors that persists over a distance of $5 \mathrm{~km}$ or more. This minimum length is based on the average length of the longest meanders measured in the area.

The second step of their approach consisted of comparing the position of the drainage anomalies with the locations of known buried anticlines (taken from geological maps or the Structural Model of Italy) [Bigi et al. 1992], to test the hypothesis of the tectonic nature of the anomalies. This analysis led Burrato et al. [2003] to: a) hypothesize a tectonic origin for a number of the drainage anomalies (shown in Figure 1, and listed in their Table I); and b) identify active structures in the subsurface (i.e., blind thrusts). Following the observation that some of these structures were also associated with historical earthquakes, Burrato et al. [2003] proposed that these blind thrusts might have been potential sources of rather infrequent large earthquakes beneath the Po Plain. In selected cases, these analyses demonstrated the concomitance of 1) the location of a critical drainage anomaly, 2) the occurrence of a buried anticline, and 3) the location of significant past earthquakes, thus supporting a causative link among these factors. It was thus possible to characterize those faults that are likely to be responsible for the largest and comparatively better known historical earthquakes (e.g., November 17, $1570, \mathrm{M}_{\mathrm{W}}$ 5.5, Ferrara; April 11, 1688, $\mathrm{M}_{\mathrm{W}}$ 5.8, Romagna; and May 12, 1802, $\mathrm{M}_{\mathrm{W}}$ 5.6, Valle dell'Oglio; Figure 1, ITIS090, ITIS100 and ITIS104). Likewise, other segments and fault systems in the area share geological and geomorphic features with the faults responsible for known earthquakes. Although these faults were not associated with a known event, they are likely to cause future earthquakes.

\section{Drainage evolution of the southern Po Plain}

The Po, Secchia, Panaro and Reno are the main rivers crossing the region that was hit by the May 20 and 29, 2012, earthquakes. These rivers show unexpected trends and behaviors (i.e., change of meander wavelength) as they cross the buried western portion of the Ferrara-Romagna Arc (Figure 2). A geological section across the area (Figure 3) shows an inner structure from the SW to the NE that was formed by buried, shallow, imbricated thrusts, known as the 


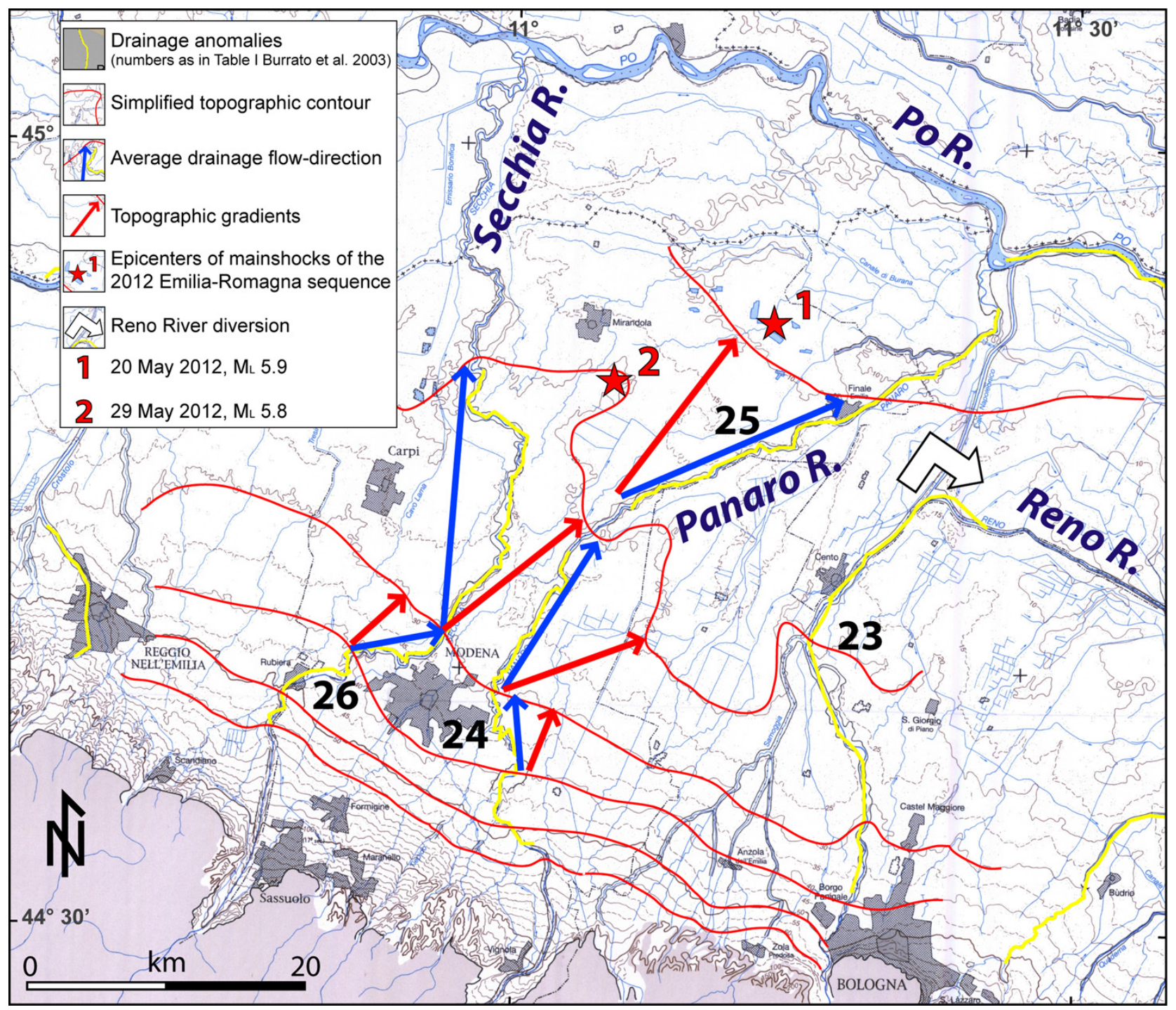

Figure 2. Drainage anomalies in the epicentral area of the 2012 Emilia-Romagna seismic sequence. The drainage should flow following the maximum regional topographic gradient; i.e., in a direction perpendicular to the smoothed topographic contour lines. The mean flow direction of each river is calculated between the contour lines. An anomaly is identified when the drainage and the topographic vectors diverge by $>10^{\circ}$ along a $>5$-km-long section of the river course. Basemap is from MURST [1997b].

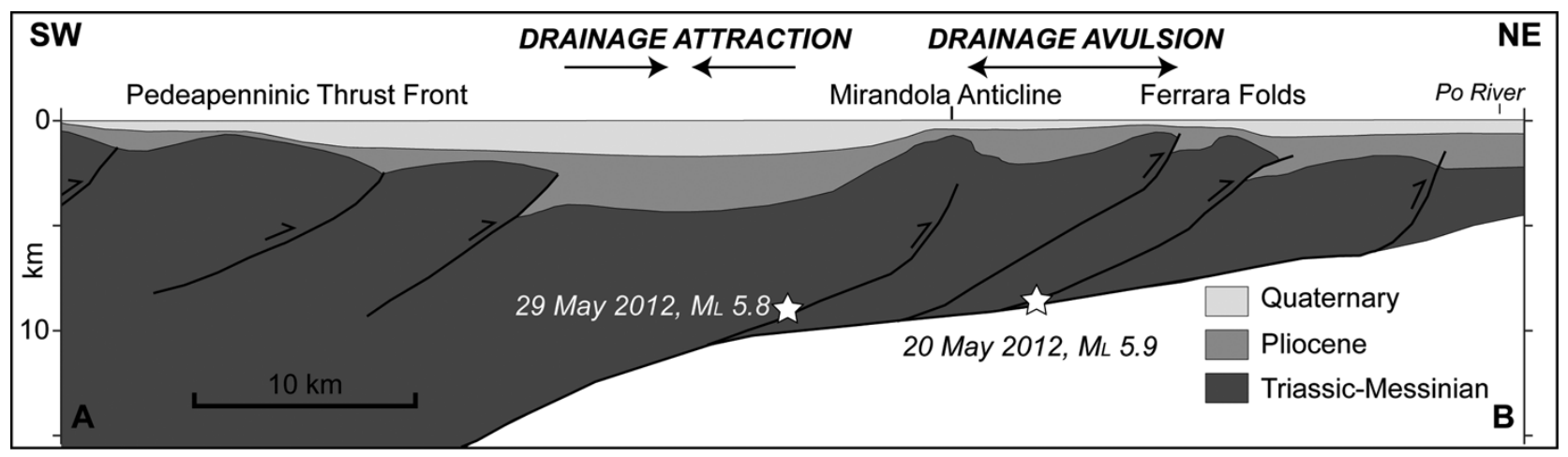

Figure 3. Simplified SW-NE geological section across the northern Apennines thrust fronts in the epicentral area of the 2012 Emilia-Romagna seismic sequence [redrawn after Carminati et al. 2010].

Pedeapenninic Thrust Front (PTF) [Boccaletti et al. 1985], a deep thrust-top basin, and the outer buried thrusts and folds of the Ferrara-Romagna Arc. In turn, the Ferrara-Romagna Arc is a complex structure that comprises an inner system of anticlines, which includes the Mirandola Anti- cline, and the outer system of the Ferrara Folds.

The May 20 and 29, 2012, earthquakes ruptured two independent parts of these blind structures. Very little historical seismicity has been reported for this region, with the notable exception of the 17 November $1570, M_{W} 5.5$, Ferrara 


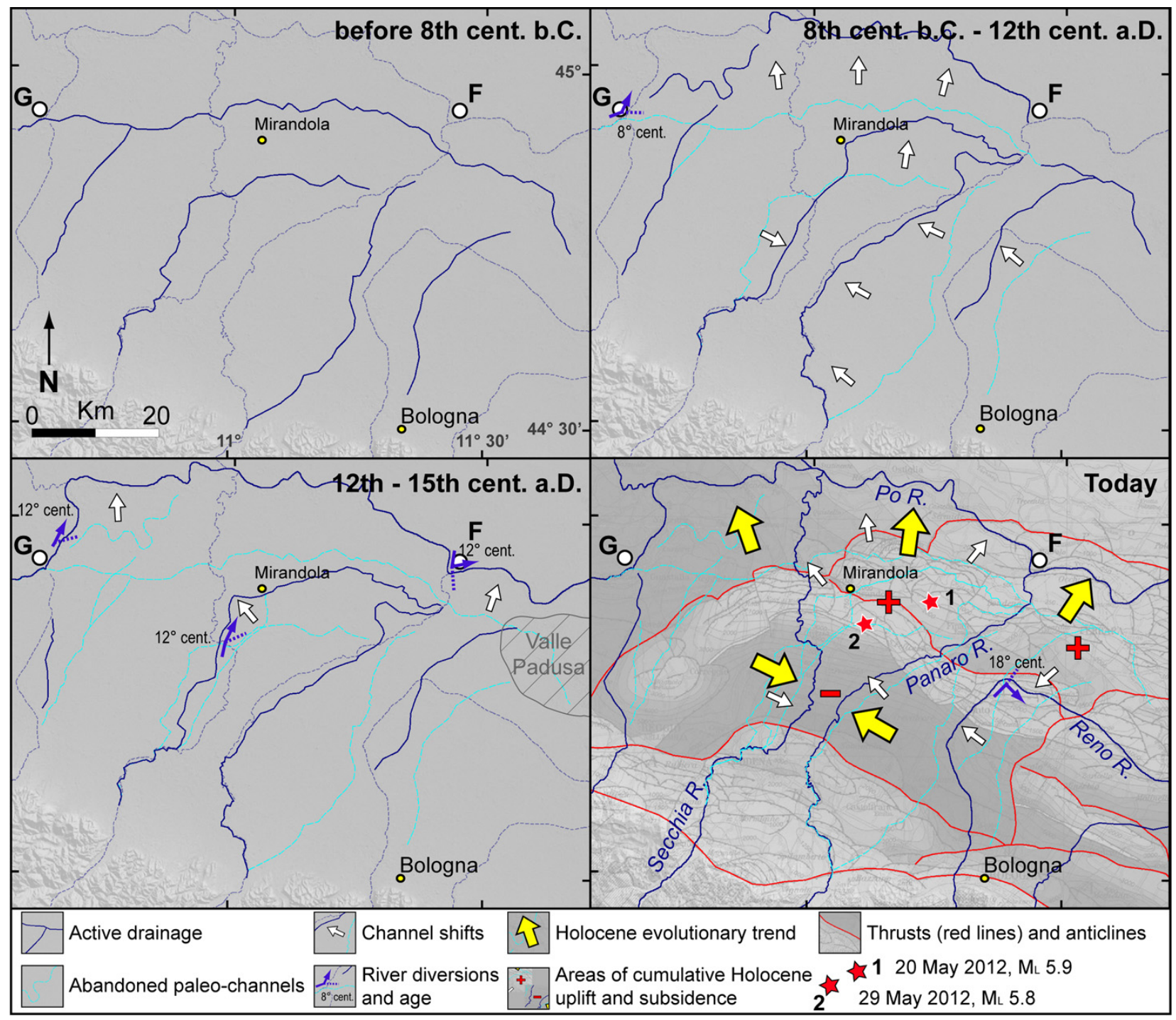

Figure 4. Drainage network evolution in the central part of the southern Po Plain north of Bologna, modified after Castaldini et al. [1979] and MURST [1997a]. The modern drainage pattern is reproduced in the background of all of the panels. The basemap of the lower-right panel is from Bigi et al. [1992]. The coseismic elevation changes detected by the DInSAR technique [see Bignami et al. 2012, this volume] fit the buried syncline-anticline pair well. Rivers are attracted towards areas of relative subsidence; e.g., synclines and thrust-top basins, and diverted away from the buried growing anticlines. Age of diversions from MURST [1997a]. F, Ficarolo; G, Guastalla.

earthquake, which was located to the northeast of the 2012 sequence, and which was probably generated by one of the outermost shallow thrusts of the Ferrara Folds (Figure 1) [Rovida 2004, Toscani et al. 2009, DISS Working Group 2010]. The 1570 aftershocks were numerous and the largest comparable in size to the mainshock - much like the 2012 sequence.

The trends of the Po, Secchia, and Panaro River channels highlight: a) an area of drainage attraction, and b) an area of drainage avulsion (Figures 2, 4). The attraction is observed where the thrust-top basin is confined between the buried outer folds and the PTF, whereas the avulsion coincides with the buried outer anticlines. The Reno River shows a sharp diversion towards the southeast that appears to be closely controlled by the growth of the Ferrara Folds (Figures 2, 3, 4). All of these rivers flow in a sub-horizontal, aggradational alluvial plain of Holocene age. They have meandering channels, the wavelength of which is controlled by the river stream-power (longer for larger rivers), and in some instances they flow along suspended beds that have been generated by the continuous aggradation caused by the slow subsidence in the area. The Po River is the longest river in Italy, draining longitudinally the entire Po Plain. The Secchia and Panaro Rivers are tributaries of the Po River, whereas the Reno River originally discharged into a paleo-channel of the Po that was abandoned in the 12th century, when the Po River changed course at Ficarolo and drifted northwards (F in Figure 4) [Bondesan 2001]. Following this diversion, the Reno River began to discharge first into a marshy area (Valle Padusa), then directly into the sea after major reclamation works (Figure 4).

The Holocene evolution of the Po, Secchia, Panaro and Reno Rivers has been reconstructed through existing mapping and dating of the alluvial deposits and paleo-channels [e.g., Castaldini et al. 1979, MURST 1997a, Castiglioni et al. 1999] (Figure 4). The oldest known course of the Po River was between Guastalla and Ficarolo (G and F in Figure 4), and it initially followed a straight E-W direction across the 
buried folds of the northern Apennines outer front; then it progressively migrated northwards through repeated sudden diversions. Eventually, it adopted the present-day convexity that parallels the Ferrara-Romagna Arc, bordering it along its outer (northern) side. With an average SW-NE trend, the Secchia and Panaro Rivers instead cross the outer tectonic structures of the northern Apennines at a high angle, and in doing so share their evolutionary destiny. Crossing the thrust-top basin south of Mirandola, over time the two rivers deflected one towards the other and both towards the present-day active depocenter. Downstream of this area, their channels were diverted in opposite directions as they crossed the buried folds of the Ferrara-Romagna Arc (Figures 2, 4).

\section{Discussion and conclusions}

The Holocene evolution of the drainage network in the central sector of the Po Plain north of Bologna has followed a consistent pattern through time, highlighting areas of relatively slight subsidence and uplift that spatially correspond to the buried basin and anticlines of the outer northern Apennine fronts.

What controls the drainage pattern in this flat alluvial area? Fault dislocation theory shows that active blind faulting contributes to the changing of topographic gradients, and so drainage is a) drawn to subsiding areas, and b) diverted from uplifting areas. This circumstance is testified by the coexistence of drainage anomalies with buried anticlines all around the Po Plain (Figures 1, 3). Historical earthquake activity generated by the active thrusts, however, shows peaks at magnitudes ca. 6 , with the only notable exception being the January 3, 1117, $\mathrm{M}_{\mathrm{W}} 6.7$ Veronese event. As shown by the coseismic elevation changes caused by the $M_{L} 5.9$ and 5.8 mainshocks of the 2012 Emilia-Romagna sequence [see Bignami et al. 2012, this volume], blind faulting earthquakes in this magnitude range can cause uplift of up to ca. $10 \mathrm{~cm}$ to $30 \mathrm{~cm}$, which is probably insufficient to induce coseismic channel diversions. Therefore, the evolution of the drainage network must be interpreted on a long-term perspective (10,000-50,000 y) and must take into consideration regional-scale tectonic and nontectonic processes, including local structural and kinematic variations and localized compaction effects. The uneven thickness of the Plio-Quaternary sedimentary sequence controls ground elevation changes induced by differential compaction, in their turn controlled by the thickness of the sediments involved (among other factors). Young, water-rich sediments thicken in the synclines and get thinner over the anticlines; hence the subsurface geometry of the recent sediments alone can induce relative differential vertical ground variations, mimicking those produced by tectonic activity, and indeed amplifying them significantly. A detailed study of the Mirandola Anticline using back-stripping of high-resolution Middle Pleistocene stratigraphic data highlighted that differential compaction might account for up to $50 \%$ of the relative vertical separation between the anticline high and the syncline low [Scrocca et al. 2007, Maesano et al. 2011].

In spite of these difficulties, analysis of drainage networks is shown to be a powerful tool for identification of buried growing anticlines, and together with fault dislocation modeling, for the characterization of the geometry of the blind thrusts driving them. This approach led to the inclusion of the Mirandola thrust in the DISS database since its first published version [Valensise and Pantosti 2001] (see also Figure 1). We propose to use the experience gained with the identification and parameterization of the Mirandola seismogenic source to investigate other blind seismogenic sources in the Po Plain and in other alluvial plains worldwide.

\section{References}

Bartolini, C., R. Caputo and M. Pieri (1996). Pliocene-Quaternary sedimentation in the northern Apennine foredeep and related denudation, Geol. Mag., 133, 255-273.

Basili, R., G. Valensise, P. Vannoli, P. Burrato, U. Fracassi, S. Mariano, M.M. Tiberti and E. Boschi (2008). The Database of Individual Seismogenic Sources (DISS), version 3: summarizing 20 years of research on Italy's earthquake geology, Tectonophysics, 453, 20-43; doi:10.1016/j.tecto. 2007.04.014.

Bigi, G., G. Bonardi, R. Catalano, D. Cosentino, F. Lentini, M. Parotto, R. Sartori, P. Scandone and E. Turco, eds. (1992). Structural Model of Italy 1:500,000, CNR Progetto Finalizzato Geodinamica.

Bignami, C., P. Burrato, V. Cannelli, M. Chini, E. Falcucci, A. Ferretti, S. Gori, C. Kyriakopoulos, D. Melini, M. Moro, F. Novali, M. Saroli, S. Stramondo, G. Valensise and P. Vannoli (2012). Coseismic deformation pattern of the Emilia 2012 seismic sequence imaged by Radarsat-1 interferometry, Annals of Geophysics, 55 (4); doi:10.4401/ ag-6157.

Boccaletti, M., M. Coli, C. Eva, G. Ferrari, G. Giglia, A. Lazzarotto, F. Merlanti, R. Nicolich, R. Papani and D. Postpischl (1985). Considerations on the seismotectonics of the northern Apennines, Tectonophysics, 117, 7-38.

Bondesan, M. (2001). L'evoluzione idrografica e ambientale della pianura ferrarese negli ultimi 3.000 anni, In: Storia di Ferrara, Ferrara, vol. I, pp. 228-263.

Burrato, P., F. Ciucci and G. Valensise (2003). An inventory of river anomalies in the Po Plain, northern Italy: evidence for active blind thrust faulting, Annals of Geophys., 46 (5), 865-882.

Carminati, E., D. Scrocca and C. Doglioni (2010). Compaction-induced stress variations with depth in an active anticline: northern Apennines, Italy, J. Geophys. Res., 115, B02401; doi:10.1029/2009JB006395.

Carminati, E., and C. Doglioni (2012). Alps vs. Apennines: The paradigm of a tectonically asymmetric Earth, Earth Sci. Rev., 112, 67-96; doi:10.1016/ j.earscirev.2012.02.004. 
Castaldini, D., G. Gasperi, M. Panizza and M. Pellegrini (1979). Neotettonica dei Fogli 74 (Reggio nell'Emilia) (p.p.) e 75 (Mirandola) nell'intervallo da 18.000 B.P. all'Attuale (interv. V), C.N.R., Nuovi contributi alla realizzazione della Carta Neotettonica di Italia, Progetto Finalizzato Geodinamica, Publ. n. 251, 317-332.

Castello, B., G. Selvaggi, C. Chiarabba and A. Amato (2006). CSI Catalogo della Sismicità Italiana 1981-2002, versione 1.1. INGV-CNT, Roma; http: / / www.ingv.it/CSI/

Castiglioni, G.B., A. Biancotti, M. Bondesan, G.C. Cortemiglia, C. Elmi, V. Favero, G. Gasperi, G. Marchetti, G. Orombelli, G.B. Pellegrini and C. Tellini (1999). Geomorphologic map of the Po Plain, Italy, at a scale of 1:250000, Earth Surf. Proc. Land., 24, 1115-1120, doi: 10.1002/(SICI)1096-9837(199911). Costa, C., F.A. Audemard, F.H.R. Bezerra, A. Lavenu, M.N. Machette and G. París (2006). An overview of the main Quaternary deformation of South America, Revista de la Asociación Geológica Argentina, 61, 461-479.

Devoti, R., A. Esposito, G. Pietrantonio, A.R. Pisani and F. Riguzzi (2011). Evidence of large scale deformation patterns from GPS data in the Italian subduction boundary, Earth Planet. Sci. Lett., 311, 230-241, doi:10.1016/j.epsl. 2011.09.034.

DISS Working Group (2010). Database of Individual Seismogenic Sources (DISS), version 3.1.1: a compilation of potential sources for earthquakes larger than M 5.5 in Italy and surrounding areas; http: / / diss.rm.ingv.it/ diss / Guidoboni, E., G. Ferrari, D. Mariotti, A. Comastri, G. Tarabusi and G. Valensise (2007). CFTI4Med, Catalogue of Strong Earthquakes in Italy (461 B.C.-1997) and the Mediterranean Area (760 B.C.-1500), INGV-SGA; http: / / storing.ingv.it/cfti4med/

Holbrook, J., and S.A. Schumm (1999). Geomorphic and sedimentary response of rivers to tectonic deformation: A brief review and critique of a tool for recognizing subtle epeirogenic deformation in modern and ancient settings, Special issue on Tectonics of Continental Interiors, Tectonophysics, 305, 287-306; doi:10.1016/S0040-1951(99) 00011-6.

ISIDe Working Group (2010). Italian Seismological Instrumental and Parametric Database; http: / / iside.rm.ingv.it

Maesano, F., C. D'Ambrogi, P. Burrato and G. Toscani (2011). Slip-rates of the buried northern Apennines thrust fronts from 3D modeling of key geological horizons (Po Plain, northern Italy), Geoitalia 2011, Epitome, 4.

Mariotti, G., and C. Doglioni (2000). The dip of the foreland monocline in the Alps and Apennines, Earth Planet. Sci. Lett., 181, 191-202.

Montone, P., and M.T. Mariucci (1999). Active stress along the NE external margin of the Apennines: the Ferrara arc, northern Italy, J. Geodyn., 28, 251-265; http: / / dx.doi. org/10.1016/S0264-3707(98)00041-6

Montone, P., M.T. Mariucci and S. Pierdominici (2012). The
Italian present-day stress map, Geophys. J. Int., 189, 705716; doi: 10.1111/j.1365-246X.2012.05391.x.

MURST (1997a). Geomorphological map of the Po Plain, scale 1:250,000, 3 sheets, S.EL.CA., Firenze.

MURST (1997b). Map of relief and vertical movements of the Po Plain, scale 1:250,000, 3 sheets, S.EL.CA., Firenze.

Pondrelli, S., S. Salimbeni, G. Ekstrom, A. Morelli, P. Gasperini and G. Vannucci (2006). The Italian CMT dataset from 1977 to the present, Phys. Earth Planet. Int., 159, 286-303; doi:10.1016/j.pepi.2006.07.008.

Rovida, A. (2004). Assessment of seismogenic sources through geological and seismological data: examples from the Andes and the Apennines, MS Thesis, Università degli Studi di Milano-Bicocca, unpublished.

Rovida, A., R. Camassi, P. Gasperini and M. Stucchi, eds. (2011). CPTI11, the 2011 version of the Parametric Catalogue of Italian Earthquakes, Milano, Bologna; available at: http: / / emidius.mi.ingv.it/CPTI/

Schumm, S.A., and H.R. Khan (1972). Experimental study of channel patterns, Geol. Soc. Am. Bull., 83, 1755-1770.

Scognamiglio, L., L. Margheriti, F.M. Mele, E. Tinti, A. Bono, P. De Gori, V. Lauciani, F.P. Lucente, A.G. Mandiello, C. Marcocci, S. Mazza, S. Pintore and M. Quintiliani (2012). The 2012 Pianura Padana Emiliana seimic sequence: locations, moment tensors and magnitudes, Annals of Geophysics, 55 (4); doi:10.4401/ag-6159.

Scrocca, D., E. Carminati, C. Doglioni and D. Marcantoni (2007). Slab retreat and active shortening along the central-northern Apennines, In: O. Lacombe, J. Lavé, F. Roure and J. Verges (eds.), Thrust belts and Foreland Basins: from fold kinematics to hydrocarbon systems, Springer, 471-487.

Stein, R., and R.S. Yeats (1989). Hidden earthquakes, Sci. Am., 260, 48-57.

Toscani, G., P. Burrato, D. Di Bucci, S. Seno and G. Valensise (2009). Plio-Quaternary tectonic evolution of the northern Apennines thrust fronts (Bologna-Ferrara section, Italy): seismotectonic implications, B. Soc. Geol. Ital. (Italian Journal of Geosciences), 128, 605-613, doi:10.3301.IJG 2009.128.2.605.

Valensise, G., and D. Pantosti, eds. (2001). Database of potential sources for earthquakes larger than M 5.5 in Italy, Annali di Geofisica, Supplement to vol. 44 (4), 180 pp., with CD-ROM.

${ }^{\star}$ Corresponding author: Pierfrancesco Burrato, Istituto Nazionale di Geofisica e Vulcanologia, Sezione Roma 1, Roma, Italy; email: pierfrancesco.burrato@ingv.it.

C 2012 by the Istituto Nazionale di Geofisica e Vulcanologia. All rights reserved. 